\title{
ANALYSIS OF TRACE ELEMENTS IN THE BHQ ICE CORE, LAW DOME, ANTARCTICA*
}

\author{
By Liu Yun-Gang, Zhang Yun-Hui, Li Gui-Qun, Xiao Lun, \\ (Institute of Atomic Energy, P.O. Box 275-58, Beijing, China)
}

and $\mathrm{XIE} \mathrm{ZI}-\mathrm{CHU}$

(Lanzhou Institute of Glaciology and Geocryology, Academia Sinica, Lanzhou, China)

\begin{abstract}
Trace elements in ice samples taken from Law Dome, Antarctica, were analysed using an instrumental neutron-activation analysis technique. A Jupiter multichannel analyser-computer system coupled to a $\mathrm{Ge}(\mathrm{Li})$ detector was used for the acquisition of $\gamma$-spectra and for data reduction. "Blanks" in water and in nitric acid, which were used in pre-concentration and sample transfer, were also analysed. To check the validity of this analytical procedure, a U.S. Environment Protection Agency water standard for trace elements was also analysed. The observed values agreed with the certified values.

The results (in ppb) of eight elements are:

$\begin{array}{llllllll}\mathrm{Na} & 209 & \mathrm{Mn} & 0.42 & \mathrm{Mg} & 26 & \mathrm{Fe} & 14 \\ \mathrm{Sc} & 0.0017 & \mathrm{Co} & 0.028 & \mathrm{Al} & 9.6 & \mathrm{Se} & 0.02\end{array}$

The enrichment factors for these eight elements relative to the Earth's crust were calculated. These elements can be subdivided into three groups or sources according to their enrichment factors. The variations of elemental concentrations with depth show no positive tendency towards a systematic increase or decrease over the past 5000 years.
\end{abstract}

\section{INTRODUCTION}

Antarctica is the continent least affected by human activities. It is covered by the permanently frozen ice sheet, which is an accumulation of snow layers deposited in the past thousands of years. Much information has been recorded chronologically within the ice sheet. Examples of this information include an estimate of the temperature at the time the snow was deposited (Lorius and others, 1979) and the atmospheric chemical elements contained in snow precipitation (Murozumi and others, 1969; Boutron, 1982). The concentrations of the elements preserved in the ice indicate their origin, their variation throughout history, and the impact of modern environmental pollution on remote areas. The early studies of trace elements in the Antarctic ice sheet up to 1969 have been summarized by Murozumi and others (1969). More detailed studies have been done at the new Byrd Station ( $\mathrm{Ng}$ and Patterson, 1981), at Dome C (Boutron and Lorius, 1979; Boutron, 1980), and at the South Pole (Boutron, 1982). Recently, more reliable data have been obtained with improved sampling and decontamination procedures (Boutron and Batifol, 1985; Legrand and Delmas, 1985; Wolff and Peel, 1985a, b; Boutron, 1986). The surface-snow samples from the Antarctic traverse from Mirniy to Vostok have also been analysed as part of an investigation of the variation of elements with distance from the coastal region to the interior (Boutron and others, 1972).

* This paper was submitted to the Fourth International Symposium on Antarctic Glaciology, Bremerhaven, 4-11 September 1987, but it was not presented at the meeting (see Annals of Glaciology, Vol. 11, 1988).
A series of studies has been carried out on Law Dome, including the oxygen-isotope ratio in Core $F$ (Budd and Morgan, 1977), ice dynamics (Russell-Head and Budd, 1979), temperature distribution (Budd and others, 1976), and the study of $\mathrm{Na}, \mathrm{Mg}, \mathrm{K}$, and $\mathrm{Ca}$ concentrations (Murozumi and others, 1969; Boutron and others, 1972; Weiss and Bertine, 1973).

Various techniques have been used in the determination of elemental concentration in ice samples, such as atomic-absoption spectrometry (Boutron, 1982), isotopedilution mass spectrometry (Murozumi and others, 1969), and neutron-activation analysis (Murozumi and others, 1969; Boutron and others, 1972; Weiss and Bertine, 1973).

In this paper we report the elemental concentrations determined by neutron-activation analysis in the ice core BHQ from Law Dome, Antarctica.

\section{EXPERIMENTAL}

A general description of Law Dome and the sampling procedure has been given by Johnson and Chamberlain (1981). The BHQ core is located $50 \mathrm{~km}$ from the edge of the Antarctic ice sheet. The depth reached was $420 \mathrm{~m}$, where the estimated age is 5000 years. The ice samples that were analysed were presented by the Australian government to China in 1982. The ice samples were stored in polyethylene bags in a frozen state until the "clean operation" and the pre-concentration processes began. To reduce any possible suface contamination, the surface layers were mechanically removed using a titanium knife, because titanium, unlike steel, will not produce any detectable radioactivity under neutron activation. Then, the cleaned ice samples, weighing approximately $100 \mathrm{~g}$, were put into Teflon beakers and sub-boiling evaporation was carried out under a vacuum at room temperature for pre-concentration. The concentrates were tranferred to polyethylene or quartz vials and evaporation continued to dryness, and then subjected to both short- and long-term activation, respectively, in a $1 \mathrm{MW}$ nuclear reactor at the Institute of Atomic Energy in Beijing. For short-term activation, the samples in the polyethylene vials were transferred into the reactor by a pneumatic system and activated for $3 \mathrm{~min}$ with a neutron flux of $1 \times 10^{13} \mathrm{n} \mathrm{cm}^{-2} \mathrm{~s}^{-1}$. $\mathrm{Na}, \mathrm{Mg}, \mathrm{Al}$, and $\mathrm{Mn}$ were determined. For long-term activation, the samples were sealed in quartz vials and activated for $10 \mathrm{~d}$ with a neutron flux of $5 \times 10^{13} \mathrm{n} \mathrm{cm}^{-2} \mathrm{~s}^{-1}$. After a certain period of decay, the quartz vials were washed with nitric acid and water, cooled with liquid nitrogen to reduce the loss of volatile elements, then opened. The activated samples were tranferred to counting vials using $1 \mathrm{NHNO}_{3}$ for long half-life nuclide measurement. A Jupiter multi-channel analyser-computer system, coupled with a $\mathrm{Ge}(\mathrm{Li})$ detector, was used for the acquisition of spectra and for data reduction. The average values of eight elements determined are given in Table I. The variations of activity measurement are: 
TABLE I. ANALYTICAL RESULTS FOR ICE SAMPLES (ppb)

$\begin{array}{lcccccccc}\text { Elements } & \mathrm{Na} & \mathrm{Mg} & \mathrm{Al} & \mathrm{Fe} & \mathrm{Mn} & \mathrm{Sc} & \mathrm{Co} & \mathrm{Se} \\ \begin{array}{l}\text { Average values } \\ \text { (BHQ 0-420 m) }\end{array} & 209 & 26 & 9.6 & 14 & 0.42 & 0.0017 & 0.028 & 0.02 \\ \mathrm{BHCl}(0.9-1.0 \mathrm{~m}) & 506 & 53 & 25 & 3.6 & 0.76 & 0.0009 & 0.011 & - \\ \mathrm{BHCl}(1.75-1.8 \mathrm{~m}) & 127 & 119 & 8.2 & 7.1 & 0.21 & 0.0003 & 0.025 & 0.09\end{array}$

$$
\begin{array}{ll}
\mathrm{Na}, \mathrm{Al}, \mathrm{Zn} & <10 \% \\
\mathrm{Sc}, \mathrm{Mn}, \mathrm{Fe}, \mathrm{Mg}, \mathrm{Co} & 10-20 \% \\
\mathrm{Se} & 20-30 \% .
\end{array}
$$

To check the validity of this analytical procedure, a water standard for trace elements, concentrate 1 of the U.S. Environment Protection Agency (EPA), was also analysed. Some of the elements related to this work are listed in Table II. The measured values agree with specified values within $10 \%$, except that the variation for $\mathrm{Cr}$ is slightly higher. For elements which are not included in the EPA standard, a similar examination has been made using a synthesized solution prepared in our laboratory.

In the procedures for cleaning containers and other equipment, and for sample pre-concentration and transfer, de-ionized water and nitric acid (super-pure grade) were used. The blank values for the water and nitric acid were determined by the same procedure using $100 \mathrm{ml}$ water and $20 \mathrm{ml}$ concentrated nitric acid. The results are shown in Table III. In the pre-concentration procedure, $5 \mathrm{ml} 1 \mathrm{~N}$ $\mathrm{HNO}_{3}$ was introduced into the sample. The associated concentrations of elements introduced into a specific sample are also listed in the last row in Table III. It can be seen that the contribution from reagents, i.e. water and nitric acid which were used in the pre-concentration, are negligible compared with the average concentrations in the ice samples. This blank determination cannot distinguish the true water and nitric acid blank from other contamination sources such as from the containers. Therefore, this estimation might be too low. The upper limit is the elemental concentrations in $100 \mathrm{ml}$ of water, that is, to suppose all water-blank values are introduced from sources other than the water itself. Even estimated by using this upper limit, it can be seen from Table III that Sc has the same magnitude, and $\mathrm{Fe}$ is up to $30 \%$ of the average values in the ice samples. The elemental concentrations in quite a few ice samples are lower than those in the water, indicating that the blank values are lower than this upper limit.

It has been demonstrated that deep ice cores are highly contaminated on the surface and the contamination will have spread towards the centre of the core. Therefore, decontamination is essential and procedures have already been described (Boutron and Batifol, 1985; Boutron, 1986). In our experiment, during the surface decontamination of ice samples, no measurements of element profiles across the ice core were made to check the decontamination efficiency. This may make the decontamination procedure insufficient for ultra-trace elements. Additionally, no estimate has been made of any contribution from the titanium knife.

\section{DISCUSSION}

\section{Comparison with reported data}

The average elemental concentrations are given in Table I. Quantitative results for Se have been obtained only for some of the samples. The elemental contents of the other samples are below the limits of detection. It is obvious that to calculate an average value using only those samples with quantitative results is highly biased. In our calculations, the elemental concentration below the limits of detection are set at zero. Of course, an average calculated in this way may be somewhat lower than the true value.

Johnson and Chamberlain (1981) reported the results for $\mathrm{Na}, \mathrm{Mg}, \mathrm{K}$, and $\mathrm{Ca}$ for the ice cores $\mathrm{F}, \mathrm{Q}$, and $\mathrm{D}$ from Law Dome. The averages for the $Q$ core (abbreviation of $\mathrm{BHQ}$ ) are 200 and $24 \mathrm{ppb}$ for $\mathrm{Na}$ and $\mathrm{Mg}$, respectively, which agree very well with our results. The concentrations of $\mathrm{Al}, \mathrm{Fe}$, and $\mathrm{Mn}$ are higher than those for the South Pole (Boutron, 1982), and Dome C (Boutron and Lorius, 1979), but of the same magnitude as the results for some sites along the profile from Mirniy (lat. $66^{\circ} 30^{\prime} \mathrm{S}$.

TABLE II. MEASUREMENT RESULTS FOR EPA WATER (ppb)

$\begin{array}{lllcccccc}\text { Element } & \mathrm{Al} & \mathrm{Fe} & \mathrm{Cr} & \mathrm{Mn} & \mathrm{Co} & \mathrm{Cu} & \mathrm{Zn} & \mathrm{Se} \\ \text { Measured values } & 65 & 14.6 & 5.1 & 7.7 & 29.6 & 8.8 & 5.9 & 8.3 \\ \text { Specified values } & 61 & 16 & 4.4 & 7.9 & 30 & 8.7 & 6.1 & 8.7 \\ \text { Variation } & +8 & -8 & +16 & -3 & -1 & +1 & -3 & -5\end{array}$

TABLE III. BLANK VALUES FOR ELEMENTAL CONCENTRATIONS IN WATER AND NITRIC ACID (ppb)

$\begin{array}{lcccccccc}\text { Elements } & \mathrm{Na} & \mathrm{Mg} & \mathrm{Al} & \mathrm{Sc} & \mathrm{Fe} & \mathrm{Mn} & \mathrm{Co} & \mathrm{Se} \\ \text { Average values } & 209 & 26 & 9.6 & 0.0017 & 14 & 0.42 & 0.028 & 0.02 \\ \text { Nitric acid } & 440 & 68 & 47 & 0.005 & 31 & 0.36 & 0.28 & - \\ \text { Water } & 6.3 & - & 2.6 & 0.002 & 5.0 & 0.05 & 0.002 & - \\ \begin{array}{l}\text { Associated } \\ \text { concentrations }\end{array} & 2.0 & 0.2 & 0.3 & 0.001 & 0.4 & 0.003 & 0.002 & -\end{array}$


long. $93^{\circ} \mathrm{E}$.; coastal region) to Vostok (lat. $78^{\circ} 27^{\prime} \mathrm{S}$., long. $107^{\circ} \mathrm{E}$., $1295 \mathrm{~km}$ from the sea) (Boutron and others, 1972). The concentration of $\mathrm{Se}$ is close to the value obtained from Greenland (Winchester and Desaedeleer, in Amiel, 1981, p. 187).

\section{Variations in elemental concentrations with depth}

The variations in the concentrations of some elements with depth are plotted in Figure 1. The concentration data are dispersed over quite a wide range. The published data on trace elements in Antarctic ice layers at different locations also show a similar dispersion (Boutron and Lorius, 1979; Boutron, 1980, 1982; Johnson and Chamberlain, 1981; Landy and Peel, 1981; Winchester and Desaedeleer, in Amiel, 1981, p. 187). If we subdivide an ice core into several sections and take the average for each section, it then seems that the concentrations for some of the elements (such as $\mathrm{Fe}, \mathrm{Co}$, and $\mathrm{Mn}$ ) are higher in the top layer. In order to examine whether this really reflects a recent increase, the surface-snow samples $\mathrm{BHCl}$ taken from the vicinity of the BHQ core were analysed (see Table I). The concentrations of these elements are not high in the surface snow. From these data, we conclude that all these elements show no positive tendency towards a systematic increase or decrease over the past 5000 years. The environmental pollution caused by increased human activity during recent times has not yet significantly influenced the remote Antarctic continent for the elements measured here. This is because human activity in Antarctica is still very limited, and Antarctica is separated by a considerable distance from the other continents. The most industrially developed parts of the world are in the Northern Hemisphere. The transfer of a polluted atmosphere to Antarctica is subject not only to the great distance but also to the barrier of the meridional circulating cells.

\section{Sources of the elements}

To evaluate the sources of these elements, the enrichment factors have been calculated and are given in Table IV. The enrichment factor is defined as:

$$
\mathrm{EF}=(\mathrm{X} / \mathrm{Al})_{\text {ice }} /(\mathrm{X} / \mathrm{Al})_{\text {crust }}
$$

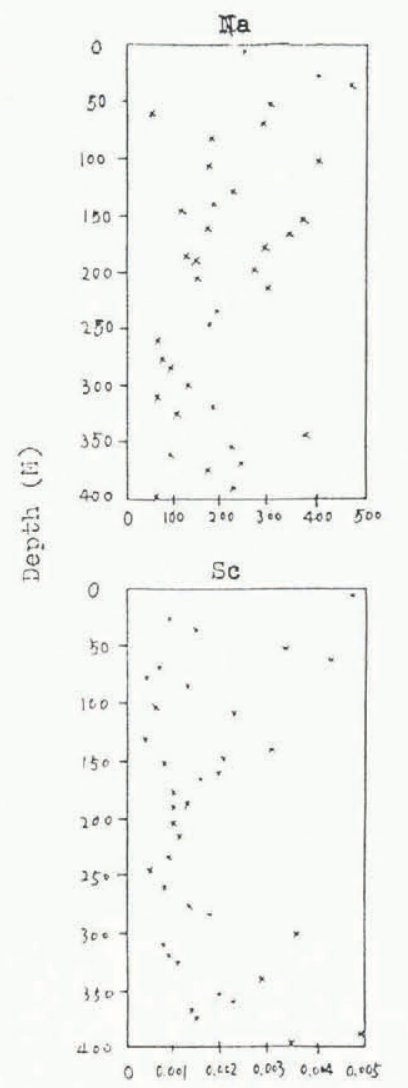

TABLE IV. ELEMENTAL ENRICHMENT FACTORS FOR ICE SAMPLES

$\begin{array}{lcccccccc}\text { Elements } & \mathrm{Na} & \mathrm{Mg} & \mathrm{Al} & \mathrm{Fe} & \mathrm{Mn} & \mathrm{Co} & \mathrm{Sc} & \mathrm{Se} \\ \text { Ice sample } & 76 & 9.6 & 1 & 2.1 & 3.8 & 9.6 & 0.66 & 3429\end{array}$

where $\mathrm{Al}$ is taken as a reference element and EF is an indication of the enrichment of element $X$ in ice relative to that in the Earth's crust. The average crustal element concentrations have been taken from Taylor (1964).

These elements can be subdivided into three groups based on their enrichment factors (Duce and others, 1975). $\mathrm{Al}, \mathrm{Fe}, \mathrm{Sc}$, and $\mathrm{Mn}$ are associated with a source largely derived from crustal materials; their enrichment factors are of the same order as that for Al.

$\mathrm{Na}$ and $\mathrm{Mg}$ are largely derived from the ocean. The $\mathrm{Na} / \mathrm{Mg}$ ratios are plotted in Figure 2 with an average of 8.5 (dashed line), which matches very well with the ratio of these two elements in sea-water (8.3) (Turekian, 1976). The major transfer mechanism is the sea-water spray generated by wave action which is carried landward by the wind. Therefore, it is easy to understand the decrease in $\mathrm{Na}$ and $\mathrm{Mg}$ in the ice with distance from the coast (Johnson and Chamberlain, 1981).

The third group is "anomalously enriched elements" (AEEs), such as Se (Duce and others, 1975; Boutron, 1982; Boutron and others, 1984). It cannot be simply interpreted as being related either to crustal or marine sources. Relatively high volatility is the property of $\mathrm{Se}$ and/or its compounds. Therefore, high-temperature processes, either natural (e.g. volcanism) or anthropogenic (e.g. combustion of fossil fuels, especially coal), may be responsible for its high enrichment. Our data show that the enrichment of $\mathrm{Se}$ is more likely to be the result of natural processes rather than anthropogenic, because there is no distinct indication to show the increase of elemental concentrations during modern times with intensification of human activity.

Co is generally considered as crustal material with an enrichment factor of 1.25 (Boutron and others, 1984). Co in
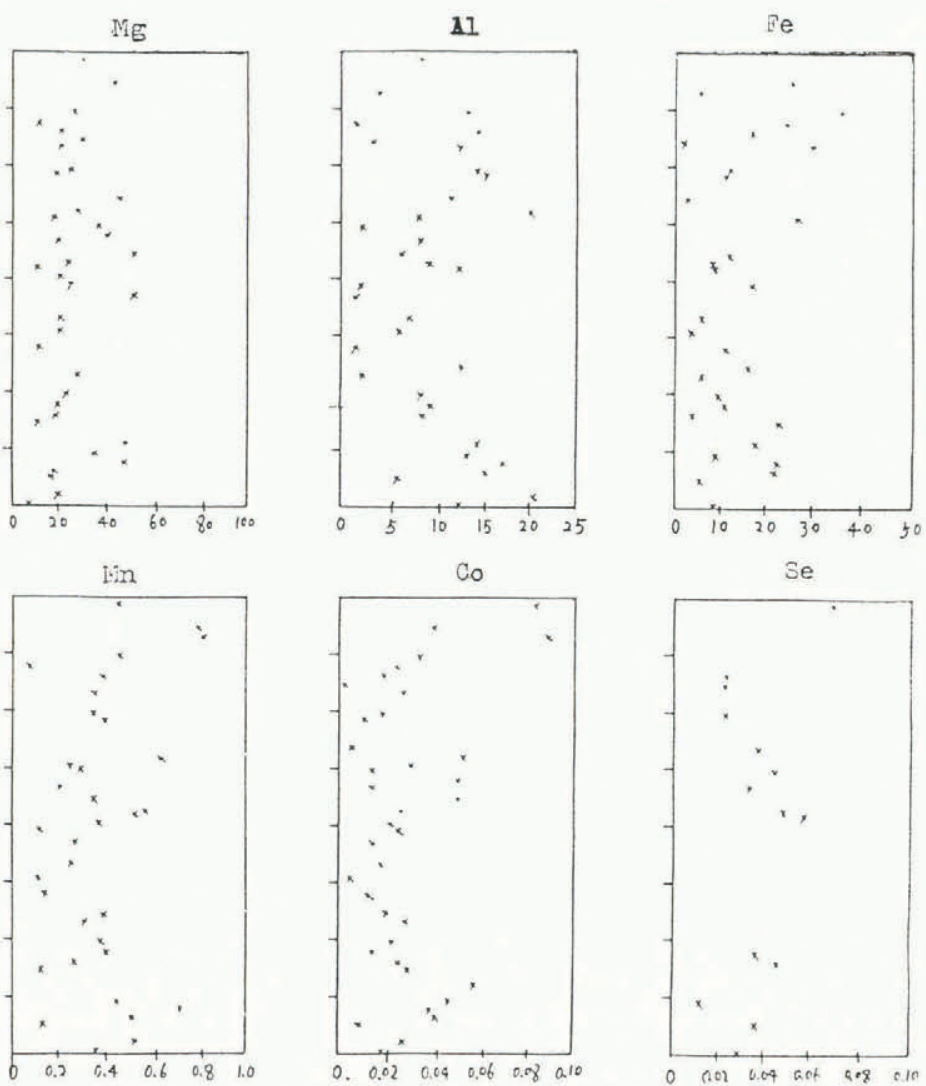

Se

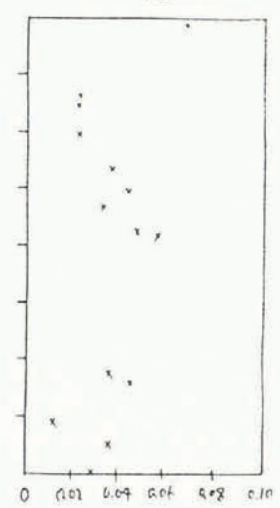

consistency (ppb)

Fig. 1. Variation of elemental concentration with depth. 


\section{Sea-water $\mathrm{ITa} / \mathrm{Mg}=8.3$}

\section{Average values 8.5}

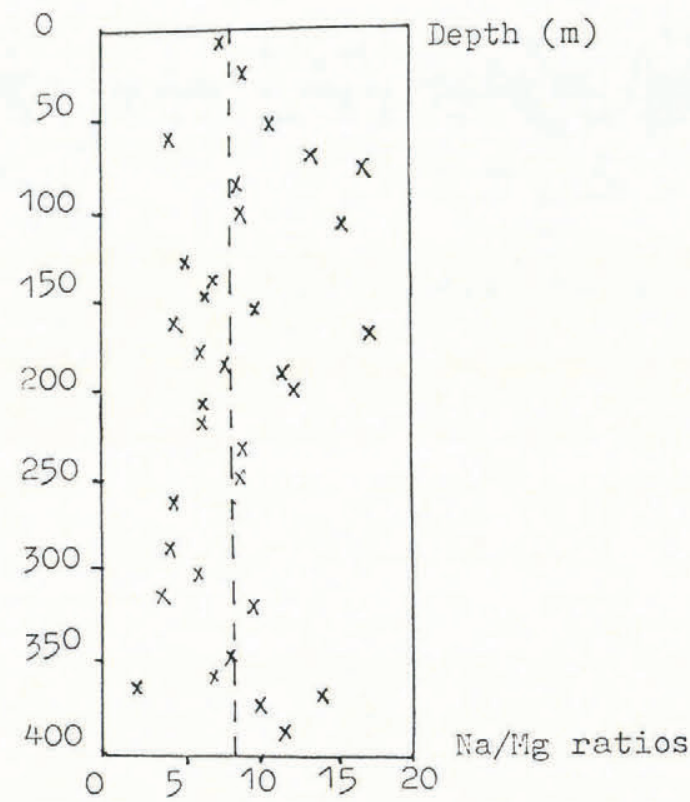

Fig. 2. Variation in $\mathrm{Na} / \mathrm{Mg}$ ratios with depth.

our ice samples might have come from a marine source through the atmosphere, either deposited by itself or carried down by the snow.

It may be worthwhile to do some work on $\mathrm{Co}$ and other elements, taking strict care of decontamination procedures and measuring their profiles across the ice core and their concentrations in the near atmosphere.

\section{REFERENCES}

Amiel, S., ed. 1981. Nondestructive activation analysis. Amsterdam, Elsevier.

Boutron, C. 1980. Respective influence of global pollution and volcanic eruptions on the past variations of the trace metals content of Antarctic snows since 1880's. J. Geophys. Res., 85(C12), 7426-7432.
Boutron, C. 1982. Atmospheric trace metals in the snow layers deposited at the South Pole from 1928 to 1977. Atmos. Environ., 16(10), 2451-2459.

Boutron, C. and C. Lorius. 1979. Trace metals in Antarctic snows since 1914. Nature, 277(5697), 551-554.

Boutron, C., M. Echevin, and C. Lorius. 1972. Chemistry of polar snows. Estimation of rates of deposition in Antarctica. Geochim. Cosmochim. Acta, 36(9), 1029-1041.

Budd, W.F. and V.I. Morgan. 1977. Isotopes, climate and ice sheet dynamics from core studies on Law Dome, Antarctica. International Association of Hydrological Sciences Publication 118 (General Assembly of Grenoble 1975 - Isotopes and Impurities in Snow and Ice), 312-321.

Budd, W.F., N.W. Young, and C.R. Austin. 1976. Measured and computed temperature distributions in the Law Dome ice cap, Antarctica. J. Glaciol., 16(74), 99-110.

Duce, R.A., G.L. Hoffman, and W.H. Zoller. 1975. Atmospheric trace metals at remote Northern and Southern Hemisphere sites: pollution or natural? Science, 187(4171), 59-61.

Johnson, B.B. and J.M. Chamberlain. 1981. Sodium, magnesium, potassium and calcium concentrations in ice cores from the Law Dome, Antarctica. Geochim. Cosmochim. Acta, 45(5), 771-776.

Landy, M.P. and D.A. Peel. 1981. Short-term fluctuations in heavy metal concentrations in Antarctic snow. Nature, 291(5811), 144-146.

Lorius, C., L. Merlivat, J. Jouzel, and M. Pourchet. 1979. A $30,000-y r$ isotopic climatic record from Antarctic ice. Nature, 280(5724), 644-648.

Murozumi, M., T.J. Chow, and C. Patterson. 1969. Chemical concentrations of pollutant lead aerosols, terrestrial dusts and sea salts in Greenland and Antarctic snow strata. Geochim. Cosmochim. Acta, 33(10), 1274-1294.

$\mathrm{Ng}$, A. and C.C. Patterson. 1981. Natural concentrations of lead in ancient Arctic and Antarctic ice. Geochim. Cosmochim. Acta, 45(11), 2109-2121.

Russell-Head, D.S. and W.F. Budd. 1979. Ice-sheet flow properties derived from bore-hole shear measurements combined with ice-core studies. J. Glaciol., 24(90), 117-130.

Taylor, S.R. 1964. Abundance of chemical elements in the continental crust: a new table. Geochim. Cosmochim. Acta, 28, $1273-1285$.

Turekian, K.K. 1976. Oceans. Second edition. New York, Prentice-Hall.

Weiss, H.V. and K.K. Bertine. 1973. Simultaneous determination of manganese, copper, arsenic, cadmium, antimony and mercury in glacial ice by radioactivation. Anal. Chim. Acta, 65(2), 253-259.

Wolff, E.W. and D.A. Peel. 1985. The record of global pollution in polar snow and ice. Nature, 313(6003), 535-540. 